\title{
One Cell-One Immunoglobulin
}

\section{ORIGIN OF LIMITED HETEROGENEITY OF MYELOMA PROTEINS}

\author{
By Z. L. AWDEH,* A. R. WILLIAMSON AND BRIGITTE A. ASKONAS \\ National Institute for Medical Research, Mill Hill, London N.W.7, U.K.
}

(Received 22 August 1969)

\begin{abstract}
Plasma-cell tumour 5563 forms a single molecular species of immunoglobulin $\mathrm{IgG}_{2} \mathrm{a}$, i.e. one variant of heavy chain and one variant of light chain. The molecules formed are labile and undergo alterations in charge properties, which rapidly lead to heterogeneity of the myeloma protein after synthesis. The single immunoglobulin species originally formed is found only after the shortest time-intervals tested, i.e. 10 min incubation. Two types of changes in charge properties take place: (1) The originally formed protein (component $o$ ) is converted via an intermediate $o^{\prime}$ into the most basic form of 5563 myeloma protein found in serum (component $a$ ). Charge differences between these components are suppressed at $\mathrm{pH} 8.9$, but can be studied by chromatography at $\mathrm{pH} 6.5$ or by analysis of isoelectric points by isoelectric focusing in polyacrylamide gel. The conversion of components $o$ and $o^{\prime}$ into component $a$ apparently commences soon after assembly of the molecules and proceeds to completion extracellularly. (2) The second type of charge difference that distinguishes components $a, b, c$ and $d$ is exhibited over the $\mathrm{pH}$ range 6.0-8.9, but not at acid $\mathrm{pH}$, and has been studied by electrophoresis at $\mathrm{pH} \mathrm{8.9,} \mathrm{by} \mathrm{chroma-}$ tography and by isoelectric focusing. Conversion of component $a$ into components $b, c, d$ and $e$ is only partial so that all five components can be found at decreasing concentrations in serum. Both types of charge alteration can be effected in vitro in the presence of serum, with optimum pH 8.0. None of the charge differences could be attributed to the secretion process, since a component with the same isoelectric point as component $o$ was found in secreted myeloma protein (lh). We have found no evidence to support the idea that the first type of change from component $o$ to component $a$ is due to ring formation of $N$-terminal $\left[{ }^{14} \mathrm{C}\right]$ glutamine into pyrrolid-2-one-5-carboxylic acid; however, our findings do not exclude this process happening very rapidly to a precursor of component $o$, possibly the polypeptide chain during or immediately after synthesis. In studying this point we noted that not only the heavy chains but also the $\kappa$-type light chain of mouse 5563 myeloma protein have a blocked $N$-terminus.
\end{abstract}

It has been demonstrated that in general the differentiated plasma cell is restricted in the expres. sion of its Ig $\dagger$ genes to a single class of heavy chains, a single type of light chain and a single allele for each chain as well as a single antibody specificity (Pernis, Chiappino, Kelus \& Gell, 1965; Cebra, Colberg \& Dray, 1966; Lennox \& Cohn, 1967). However, even within these restrictions, it has not so far been clearly shown that individual plasma cells produce a single molecular species of Ig. Plasma-cell tumours (myelomas) are the only plasma cells presently suitable for this type of study, since individual tumour lines appear to be derived from a

* Present address: Nutrition Research Laboratory, American University of Beirut, Beirut, Lebanon.

† Abbreviation: Ig, immunoglobulin. single cell clone. G-myeloma proteins in the sera of patients with multiple myeloma and the sera of mice bearing plasma-cell tumours show some heterogeneity of charge properties. G-myeloma protein 5563, for example, shows four or five protein bands on starch-gel electrophoresis at pH 8.9 (Askonas, 1961). This suggests that such individual cell clones express genes for several variants of heavy and light chains, since the heterogeneity of G-myeloma protein is reflected in heterogeneity of both chains (Awdeh, Williamson \& Askonas, 1969). However, we have reported previously that myeloma protein newly formed by plasma-cell tumour 5563 in vitro is far more homogeneous than the myeloma protein found in the serum of mice bearing this tumour line, and that 
conversion of newly formed protein into the components with the same charge properties as serum myeloma-protein components can be effected in vitro by incubation of the newly formed myeloma protein with serum at $37^{\circ} \mathrm{C}$ (Awdeh, Askonas \& Williamson, 1967). The present paper gives further characterization of the newly formed myeloma protein. Use has been made of radioautography and isoelectric focusing in thin layers of polyacrylamide gel, an equilibrium technique that fractionates proteins on the basis of their isoelectric point and has greater resolving power than either chromatography or zone-electrophoretic techniques. It has been established that plasma-cell tumour 5563 forms a single molecular species of IgG; thus structural genes for only a single variant of heavy chain and a single variant of light chain are expressed in the differentiated plasma cell.

After its assembly, the original homogeneous myeloma protein rapidly undergoes alterations in charge properties so that heterogeneity results. It was found that two types of change take place. The originally formed myeloma protein (component $o$ ) is completely converted into the components present in serum via an intermediate component $o^{\prime}$. The charge difference between components $o$ and $o^{\prime}$ and the serum component $a$ (least negatively charged, highest $\mathrm{p} I$ ) differs from the charge difference between components $a, b, c, d$ and $e$ in that it is suppressed at $\mathrm{pH}$ values above 8.0. This particular change would be consistent with the possible cyclization of $N$-terminal $\left[{ }^{14} \mathrm{C}\right]$ glutamine to pyrrolid-2-one-5-carboxylic acid, since both heavy and light chains of 5563 myeloma protein, as found in serum, have blocked $N$-termini; however, no $N$ terminal $\left[{ }^{14} \mathrm{C}\right]$ glutamine was detected in freshly synthesized myeloma protein. The second type of change, which is incomplete, leads to the presence of the four or five myeloma proteins $a, b, c, d$ and $e$ found in progressively decreasing concentrations in the sera of tumour-bearing mice. It seems probable that these charge differences, which are observed at alkaline $\mathrm{pH}$, but which are suppressed in acid, can be attributed to progressive loss of labile amide groups from the IgG molecules.

It is relevant to the mechanism of the secretion process that, using short incubation periods and rapid analysis, we were unable to detect any difference between the charge properties of intra- and extra-cellular myeloma protein.

\section{MATERIALS AND METHODS}

Solutions and reagents. Solution E contained $10 \mathrm{~mm}$-tris$10 \mathrm{~mm}-\mathrm{KCl}-1 \mathrm{~mm}-\mathrm{MgCl}_{2}, \mathrm{pH}$ 7.5. U- ${ }^{14} \mathrm{C}$-labelled protein hydrolysate, $\mathrm{L}-\left[{ }^{3} \mathrm{H}\right]$ leucine and $\mathrm{L}-\left[{ }^{14} \mathrm{C}\right]$ glutamine were purchased from The Radiochemical Centre, Amersham, Bucks., U.K. The protein hydrolysate was purified by adsorption on a short column of Zeo-Karb 225 and elution with $0.3 \mathrm{M}-\mathrm{NH}_{3}$. Sodium deoxycholate was obtained from British Drug Houses Ltd., Poole, Dorset, U.K. Bovine serum albumin (fraction V) was purchased from Armour Pharmaceutical Co. Ltd., Eastbourne, Sussex, U.K.

Plasma-cell tumour 5563. This tumour line was originally obtained through the kindness of Dr M. Potter, National Cancer Institute, Bethesda, Md., U.S.A., and was maintained in $\mathrm{C}_{3} \mathrm{H} / \mathrm{He}$ mice as an ascitic form by intraperitoneal transfer. The G-myeloma protein $\left(G_{2} a\right.$ with $\kappa$-type light chains) formed by the tumour stayed constant over many years of transplantation.

Purification of $G$-myeloma protein. The 5563 myeloma protein was purified from serum or ascitic fluid of tumourbearing mice by chromatography on DEAE-cellulose as described by Askonas (1961). Partial purification of Gmyeloma protein for use as a non-radioactive carrier protein was obtained by precipitation with $\left(\mathrm{NH}_{4}\right)_{2} \mathrm{SO}_{4}$ at $35 \%$ saturation at $0^{\circ} \mathrm{C}$ and reprecipitation at the same $\left(\mathrm{NH}_{4}\right)_{2} \mathrm{SO}_{4}$ concentration. The protein was dialysed against 0.01m-potassium phosphate buffer, $\mathrm{pH} 6.5$, and stored frozen.

Incubation of plasma cells with radioactive amino acids. Ascitic 5563 tumour cells were washed with Hanks medium (Hanks, 1948) and the erythrocytes lysed differentially (Williamson \& Askonas, 1967). About $2 \times 10^{8}$ tumour cells were suspended in $3 \mathrm{ml}$ of Hanks medium containing $10 \mathrm{mg}$ of bovine serum albumin $/ \mathrm{ml}$ and incubated for various times $(10 \mathrm{~min}-2 \mathrm{~h})$ at $37^{\circ} \mathrm{C}$ with $15 \mu \mathrm{Ci}$ of $\mathrm{U}-{ }^{14} \mathrm{C}$ labelled amino acids (protein hydrolysate, specific radioactivity $600 \mu \mathrm{Ci} / \mathrm{mg}$ ), or $50 \mu \mathrm{Ci}$ of $\mathrm{L}-\left[{ }^{3} \mathrm{H}\right]$ leucine (specific radioactivity $1 \mathrm{Ci} / \mathrm{mmol}$ ) or $50 \mu \mathrm{Ci}$ of $\mathrm{L}-\left[{ }^{14} \mathrm{C}\right]$ glutamine (specific radioactivity $39 \mathrm{mCi} / \mathrm{mmol}$ ). Since some glutamine may be converted into glutamic acid by the tumour cells, the incubation with $\left[{ }^{14} \mathrm{C}\right]$ glutamine was carried out in the presence of $10 \mathrm{~mm}$ non-radioactive glutamic acid. The cells were recovered by centrifugation, and the supernatant represented the extracellular fluid. The intracellular soluble protein was extracted by resuspending the cells in $0.8 \mathrm{ml}$ of solution $\mathbf{E}$ and disrupting them by addition of $0.2 \mathrm{ml}$ of $5 \%(\mathrm{w} / \mathrm{v})$ sodium deoxycholate. The lysed cells were layered on a sucrose gradient $[8 \mathrm{ml}$ of $30 \%, 1 \mathrm{ml}$ of $10 \%$ and $1 \mathrm{ml}$ of $4 \%(\mathrm{w} / \mathrm{v})$ sucrose in solution E]. After centrifugation for $1 \mathrm{~h}$ in a Spinco no. 40 rotor at $39000 \mathrm{rev}$./ min, the top $3 \mathrm{ml}$ was removed and radioactive proteins were analysed immediately by isoelectric focusing or dialysed against $0.01 \mathrm{~m}$-potassium phosphate buffer, $\mathrm{pH} 6.5$, in the cold-room and stored frozen at $-16^{\circ} \mathrm{C}$ for chromatography. The extracellular fluid was similarly analysed immediately or dialysed and stored.

Chromatography of radioactively labelled myeloma proteins. DEAE-cellulose (Whatman DE 11) was washed and treated as described by Peterson \& Sober (1956). A $5 \mathrm{~g}$ portion of DEAE-cellulose was equilibrated with $10 \mathrm{~mm}$ potassium phosphate buffer of the required $\mathrm{pH}$ and packed under pressure to give a column approx. $0.8 \mathrm{~cm} \times 30 \mathrm{~cm}$. Then $20 \mathrm{mg}$ of non-radioactive myeloma protein was mixed with the labelled sample and applied to the column, and $100 \mathrm{ml}$ of $0.01 \mathrm{M}$-potassium phosphate buffer was passed through the column before gradient elution was commenced. A linear gradient, consisting of $250 \mathrm{ml}$ each of $10 \mathrm{~mm}$ - and $50 \mathrm{~mm}$-potassium phosphate buffer of the required $\mathrm{pH}$, was pumped at a rate of $0.5 \mathrm{ml} / \mathrm{min}$. Fractions of volume $5 \mathrm{ml}$ were collected and their $E_{280}$ values measured. 
CM-cellulose (Whatman CM 11) was treated with $0.5 \mathrm{M}$ $\mathrm{NaOH}$, washed with water and equilibrated with $5 \mathrm{~mm}$ potassium phosphate buffer, $\mathrm{pH}$ 6.5. Then $5 \mathrm{~g}$ was packed under pressure to give a column $0.8 \mathrm{~cm} \times 40 \mathrm{~cm}$. The sample was applied to the column and eluted with a linear gradient consisting of $500 \mathrm{ml}$ of each of $5 \mathrm{~mm}$ - and $50 \mathrm{~mm}$ potassium phosphate buffer at a rate of $0.5 \mathrm{ml} / \mathrm{min}$. Fractions of volume $5 \mathrm{ml}$ were collected and their $E_{280}$ values determined.

Isoelectric focusing of ${ }^{14} \mathrm{C}$-labelled myeloma protein on thin layers of polyacrylamide gel. Thin-layer plates of polyacrylamide gel $23 \mathrm{~cm} \times 15 \mathrm{~cm} \times 0.1 \mathrm{~cm}$ were prepared by the polymerization of $5 \%(\mathrm{w} / \mathrm{v})$ acrylamide containing $2 \%$ (w/v) of Ampholine carrier ampholyte ( $\mathrm{pH}$ range 3.0-10.0) (LKB-Producter AB, Stockholm, Sweden), as described by Awdeh, Williamson \& Askonas (1968). Up to eight samples (about 500 c.p.m. of myeloma protein and $100 \mu \mathrm{g}$ of non-radioactive myeloma protein carrier) were applied and the isoelectric focusing was carried out in a humidjfied chamber with a potential difference of $400 \mathrm{~V}$ for $24 \mathrm{~h}$ at $2^{\circ} \mathrm{C}$. At the end of each run the proteins were stained with Coomassi Blue dye in $10 \%(w / v)$ trichloroacetic acid as described by Chrambach, Reisfeld, Wyckoff \& Zaccari (1967). The stained gel was washed extensively with water to remove trichloroacetic acid, dried at room temperature to adhere to the glass plate and set up for radioautography with an Ilford X-ray film.

N-Terminal amino acid analysis. (i) Non-radioactive protein. The protein was treated with 1-fluoro-2,4dinitrobenzene in bicarbonate-guanidine hydrochloride by the method of Phillips (1958). The resulting DNP. protein was hydrolysed with $5.7 \mathrm{M}-\mathrm{HCl}$ in a sealed tube for $16 \mathrm{~h}$ at $105^{\circ} \mathrm{C}$. The ether extract of the hydrolysate was applied to a sheet of Whatman no. 1 paper and developed in the 'toluene' system of Levy (1954).

(ii) Myeloma protein labelled with $\left[{ }^{14} \mathrm{C}\right]$ glutamine. Newly synthesized myeloma protein labelled with $\mathrm{L}-\left[{ }^{14} \mathrm{C}\right]$ glutamine was applied to a column of DEAE-cellulose. The radioactive peak was pooled, non-radioactive carrier myeloma protein added and the mixture treated with 1-fluoro-2,4-dinitrobenzene in $6 \mathrm{M}$-guanidine hydrochloride as described above. Non-radioactive carrier DNPglutamine was added to the DNP-protein and the mixture hydrolysed in $5.7 \mathrm{M}-\mathrm{HCl}$ as described above. The hydrolysate was extracted with ether. The total ether extract and samples of the aqueous layer were dried on metal planchets and the radioactivity was measured with a Nuclear-Chicago gas-flow counter.

Determination of radioactivity of protein. (i) Samples containing only ${ }^{14} \mathrm{C}$. Bovine serum albumin $(0.5 \mathrm{mg})$ was added to $1 \mathrm{ml}$ portions of each fraction and the total protein was precipitated with $5 \%(w / v)$ trichloroacetic acid. The precipitates were filtered and washed on Oxoid membranes and their radioactivities measured in a Packard Tri-Carb liquid-scintillation counter (Williamson \& Askonas, 1967).

(ii) Samples containing both ${ }^{3} \mathrm{H}$ and ${ }^{14} \mathrm{C}$. The protein content of each sample was adjusted to $1 \mathrm{mg}$ with bovine serum albumin and the protein precipitated with $5 \%$ trichloroacetic acid. The precipitate was dissolved in $0.1 \mathrm{ml}$ of $0.3 \mathrm{M}-\mathrm{NaOH}$ and transferred quantitatively into counting vials by rinsing the tubes with scintillation fluid (Williamson \& Askonas, 1967). The samples were counted in a Packard liquid-scintillation counter with channel settings such that with standard samples not more than
$0.5 \%$ of the ${ }^{3} \mathrm{H}$ counts appeared in the ${ }^{14} \mathrm{C}$ channel and $40 \%$ of the ${ }^{14} \mathrm{C}$ counts appeared in the ${ }^{3} \mathrm{H}$ channel. The radioactive mixture applied to the column was adjusted to contain a large excess of ${ }^{3} \mathrm{H}$ radioactivity over ${ }^{14} \mathrm{C}$. This minimized any error due to variation in the proportion of the ${ }^{14} \mathrm{C}$ counts appearing in the ${ }^{3} \mathrm{H}$ channel as a result of differences in quenching from one sample to another.

Nomenclature. In this paper we use nomenclature recommended by the World Health Organisation (1964). To facilitate description of the results the five $6.6 \mathrm{~S}$ myeloma protein components found in sera of mice carrying plasma-cell tumour 5563 are referred to as components $a, b, c, d$ and $e$ according to their rates of migration towards the anode on starch-gel electrophoresis at $\mathrm{pH} 8.9 ; a$ refers to the component of highest isoelectric point and $e$ to the most negatively charged myeloma protein; $o$ refers to the freshly synthesized myeloma protein that is converted into component $a$ via intermediate $o^{\prime}$ and can be distinguished from component $a$ by its chromatographic behaviour on DEAE-cellulose at $\mathrm{pH} 6.5$ (though not at $\mathrm{pH} 8.6$ ), and by its having a higher isoelectric point than component $a$ in the isoelectric-focusing technique described.

\section{RESULTS}

Chromatographic properties of newly formed myeloma protein. Using DEAE-cellulose columns at pH 6.5, we had shown previously that the radioactive myeloma protein formed during a $2 \mathrm{~h}$ incubation in vitro is eluted ahead of the myeloma protein isolated from the serum of tumour-bearing mice (Awdeh et al. 1967). However, at pH 8.9 on starchgel electrophoresis the newly formed ${ }^{14} \mathrm{C}$-labelled myeloma protein had the same electrophoretic mobility as component $a$ in serum (Z. L. Awdeh, unpublished work quoted by Askonas \& Williamson, 1967). The chromatographic properties of ${ }^{14} \mathrm{C}$-labelled 5563 myeloma protein were therefore investigated as a function of the $\mathrm{pH}$ of the eluent. Figs. 1(i) and 1(ii) show the patterns of elution from DEAE-cellulose columns at $\mathrm{pH} 6.5$ and 8.6. The chromatographic position of the radioactive myeloma protein becomes coincident with that of serum component $a$ as the $\mathrm{pH}$ is increased from 6.5 to 8.6. Over a range of $\mathrm{pH}$ values tested (6.5-8.6), the maximum chromatographic difference occurs at $\mathrm{pH} 6.5$; at pH 6.0 the myeloma protein was not adsorbed on the column.

The presently described shift in chromatographic properties, as a function of increasing $\mathrm{pH}$, is reversible. The radioactive peak chromatographing with component $a$ on DEAE-cellulose at pH 8.6 [Fig. 1(ii)] was pooled and concentrated, and the protein was dialysed against $10 \mathrm{~mm}$-potassium phosphate buffer, $\mathrm{pH} 6.5$; on rechromatography at pH 6.5 the radioactive elution pattern [Fig. 1(iv)] was the same as that for the original material [Fig. 1(i)]. At pH 8.6 the charge differences between the newly formed radioactive myeloma protein and serum component $a$ is thus suppressed. This explains 

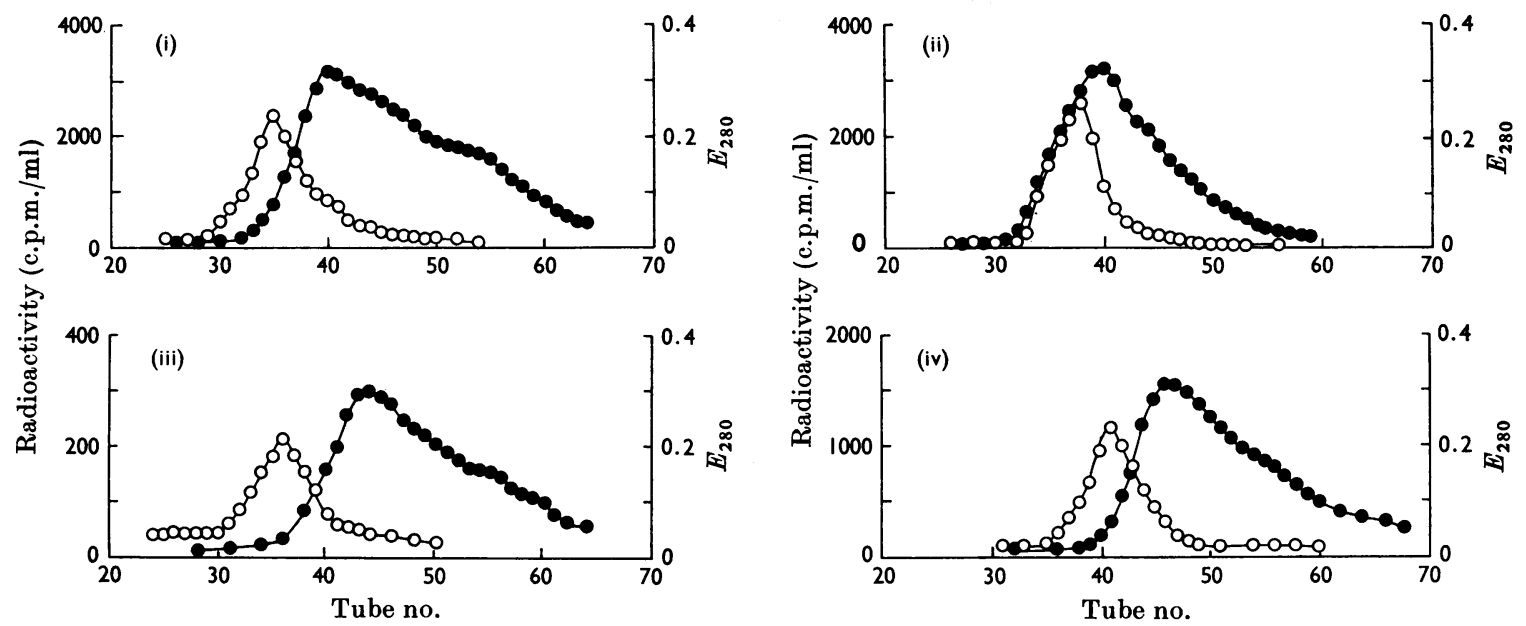

Fig. 1. Effect of $\mathrm{pH}$ on the chromatographic properties of the ${ }^{14} \mathrm{C}$-labelled extracellular 5563 myeloma protein prepared by incubating tumour cells with ${ }^{14} \mathrm{C}$-labelled amino acids for $2 \mathrm{~h}$ at $37^{\circ} \mathrm{C}$. Each sample was mixed with $20 \mathrm{mg}$ of carrier non-radioactive myeloma protein and chromatographed on DEAE-cellulose $(5 \mathrm{~g})$ with a linear gradient of potassium phosphate buffer $(10-50 \mathrm{~mm})$. Fractions of volume $5 \mathrm{ml}$ were collected. $\bullet, E_{280} ; \bigcirc$, radioactivity precipitable with $5 \%(\mathrm{w} / \mathrm{v})$ trichloroacetic acid. (i) $\mathrm{pH} 6.5$; (ii) $\mathrm{pH} 8.6$; (iii) rechromatography at pH6.5 of fractions 32 and 33 from column (i) with carrier myeloma protein; (iv) the radioactivity peak from column (ii), fractions 33 and 34 , concentrated, dialysed against $10 \mathrm{~mm}$-phosphate buffer, pH6.5, and rechromatographed at $\mathrm{pH} 6.5$ with carrier myeloma protein.

the identical behaviour of the two materials on electrophoresis at pH 8.9 (Z. L. Awdeh, unpublished work quoted by Askonas \& Williamson, 1967).

The comparatively symmetrical chromatographic pattern of the ${ }^{14} \mathrm{C}$-labelled myeloma protein suggested that it could represent a single molecular species of protein. However, the following experiment indicated differently. When protein from the leading fractions of the radioactive peak [tubes 32 and 33, Fig. 1(i)], together with additional nonradioactive myeloma protein, was rechromatographed at $\mathrm{pH} 6.5$, the ${ }^{14} \mathrm{C}$ 'ran true', i.e. it formed a peak in its original position 7-8 tubes before the carrier myeloma protein [Fig. 1(iii)]. This indicated that even the myeloma protein produced during a $2 \mathrm{~h}$ incubation in vitro is not homogeneous. Chromatography and conventional electrophoretic techniques did not resolve this heterogeneity further. Development of a technique for isoelectric focusing on thin layers of polyacrylamide (Awdeh et al. 1968) did, however, make further resolution possible, as described in the next section.

Characterization of newly formed myeloma protein by isoelectric focusing and radioautography. To minimize changes that may occur in the newly formed myeloma protein, the duration of the pulse of ${ }^{14} \mathrm{C}$-labelled amino acids was decreased from $2 \mathrm{~h}$ to $10 \mathrm{~min}$. The resultant labelled protein was examined by isoelectric focusing on thin layers of polyacrylamide gel (Awdeh et al. 1968) followed by radioautography. The radioautograph shows mainly one band of myeloma protein, with a trace of a second band; these have been designated components $o$ and $o^{\prime}$ respectively [Plate 1(iii)]. To relate this homogeneous product labelled during a $10 \mathrm{~min}$ pulse to the previous chromatographic results, myeloma protein labelled during longer exposure of ascitic cells to ${ }^{14} \mathrm{C}$-labelled amino acids was examined. With increasing duration of labelling the isoelectric focusing pattern of radioactive myeloma protein became more heterogeneous. Myeloma protein synthesized and retained intracellularly during a $\mathrm{lh}$ incubation showed three major components corresponding to components $o$ and $o^{\prime}$ seen at earlier times, and component $a$, the most basic form of myeloma protein found in serum (Plates 1 and 2). The isoelectric point of component $a$ was identical with that of the intracellular myeloma protein component with the lowest $\mathrm{p} I$ as revealed by a comparison of the pattern of nonradioactive carrier myeloma-protein components with radioautography of the same gels (see the Materials and Methods section and Plate 2). The stained protein bands of the carrier myeloma protein are components $a, b$ and $c$, as isolated from the serum of tumour-bearing mice.

The heterogeneity of the $1 \mathrm{~h}$ intracellular ${ }^{14} \mathrm{C}$ labelled myeloma protein that was inferred from 


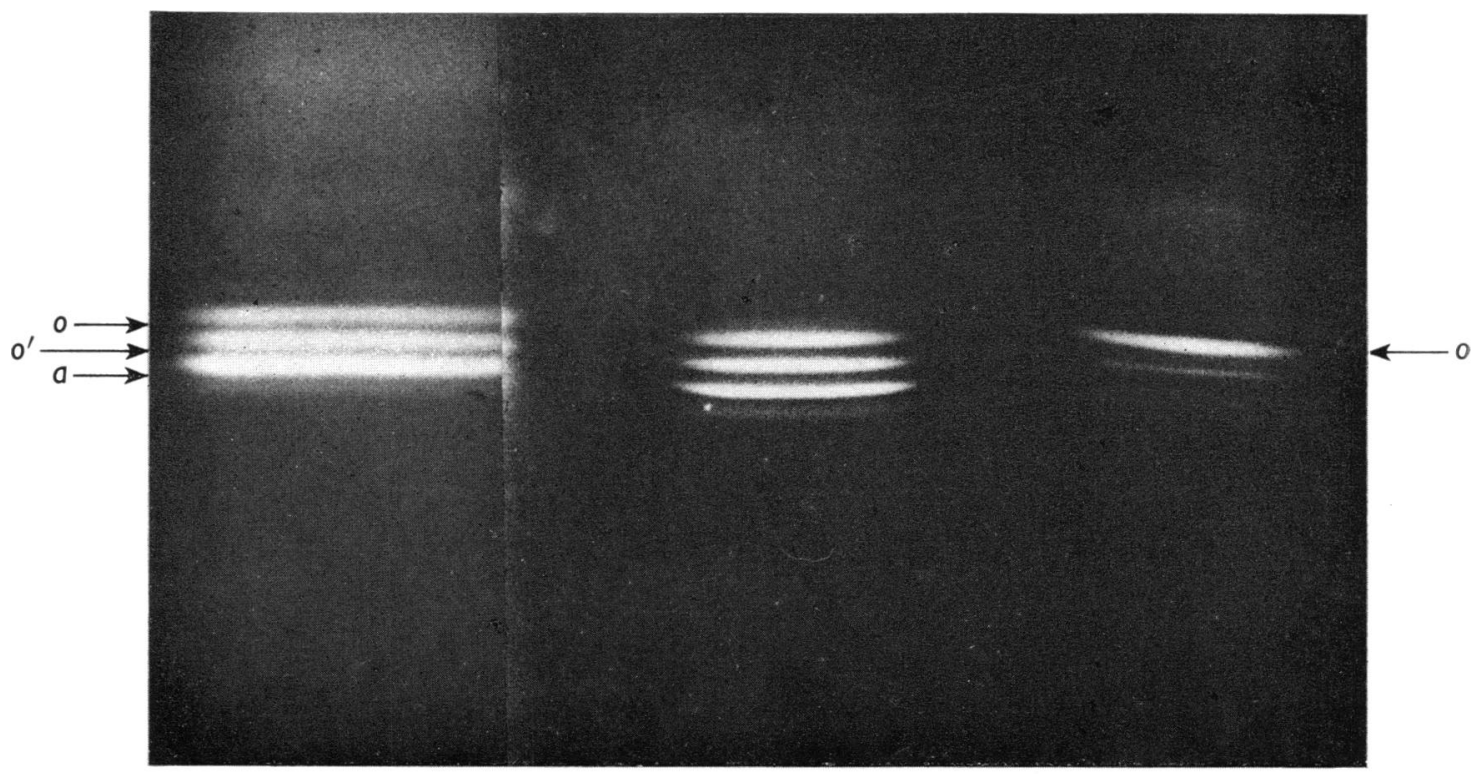

(i)

(ii)

(iii)

Anode

\section{EXPLANATION OF PLATE I}

Radioautograph of polyacrylamide-gel plate after isoelectric focusing, with Ampholine, $\mathrm{pH} 3-10 .{ }^{14} \mathrm{C}$ labelled intracellular or extracellular myeloma protein was analysed after incubation of 5563 plasmacytes with ${ }^{14} \mathrm{C}$-labelled amino acids at $37^{\circ} \mathrm{C}$ for $10 \mathrm{~min}$ or $1 \mathrm{~h}$ as indicated. (i) Intracellular myeloma protein, $1 \mathrm{~h}$ incubation; (ii) extracellular myeloma protein harvested after $1 \mathrm{~h}$ of incubation; (iii) intracellular myeloma protein, $10 \mathrm{~min}$ incubation. 


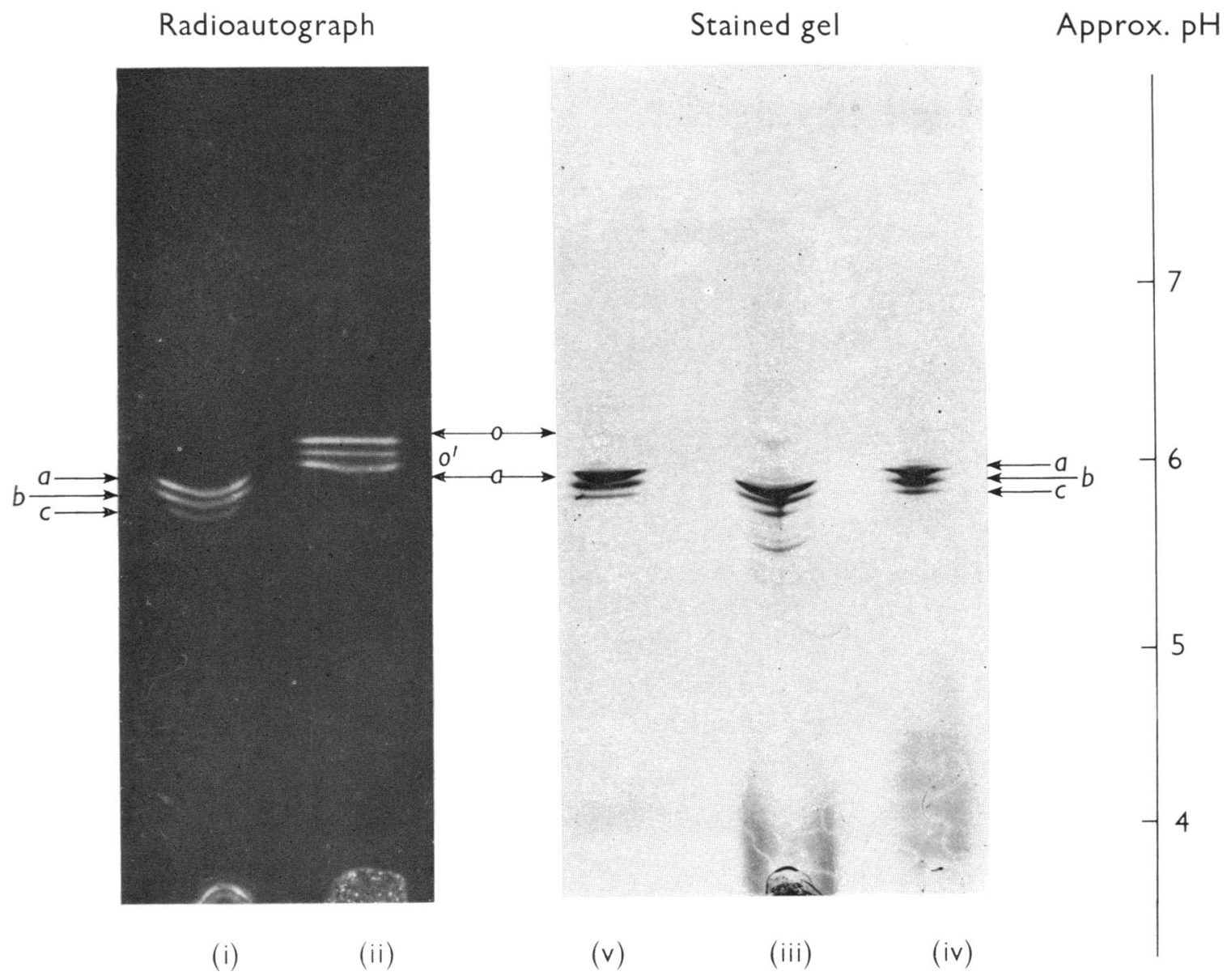

EXPLANATION OF PLATE 2

Comparison of isoelectric points of ${ }^{14} \mathrm{C}$-labelled extracellular myeloma protein before and after serum treatment. The 5563 plasma cells were incubated for $1 \mathrm{~h}$ with ${ }^{14} \mathrm{C}$-labelled amino acids, carrier myeloma protein isolated from sera of tumour-bearing mice was added and the samples were analysed by isoelectric focusing on polyacrylamide gel in Ampholine, $\mathrm{pH} 3-10$. Radioautographs: (i) ${ }^{14} \mathrm{C}$-labelled myeloma protein incubated with sterile mouse serum overnight at $37^{\circ} \mathrm{C}$ at $\mathrm{pH} 8.0$; (ii) ${ }^{14} \mathrm{C}$-labelled myeloma protein before treatment with mouse serum. Same polyacrylamide-gel plate stained for protein with Coomassi Blue: (iii) sample (i) showing stained carrier myeloma protein; (iv) sample (ii) showing stained carrier myeloma protein; ( $v$ ) stained carrier myeloma protein. 
the results of chromatography was thus completely resolved by isoelectric focusing. This technique showed that the 5563 tumour does form only a single molecular species of $\mathrm{Ig}$, but that this $\mathrm{Ig}$ is quickly subjected to alterations in its charge properties; consequently a single component is only in evidence intracellularly at the shortest time measured, i.e. $10 \mathrm{~min}$.

We have previously reported (Awdeh et al. 1967) that the alteration in charge properties of myeloma protein leading to conversion of component $a$ into $b$ into $c$ etc. can be mimicked in vitro by incubation with serum. Similarly we have now shown that alterations of components $o$ and $o^{\prime}$ can be effected by treatment with serum. Myeloma protein labelled and secreted during a $1 \mathrm{~h}$ incubation with ${ }^{14} \mathrm{C}$ labelled amino acids was incubated with serum at pH 8.0 overnight at $37^{\circ} \mathrm{C}$. There was a complete disappearance of components $o$ and $o^{\prime}$ with the generation of components $b$ and $c$ [Plates 2(i and 2(ii)].

Comparison of intracellular and extracellular $G$ myeloma protein. Notani, Munro \& Knopf (1966) reported a difference on polyacrylamide-gel electrophoresis between intracellular and secreted myeloma protein in tumour lines APC-5 and MOPC 21, and suggested that carbohydrate addition occurring just before secretion might be responsible for this change. In view of this report we reinvestigated this question in plasma-cell tumour 5563 by examining the chromatographic properties of a mixture of ${ }^{14} \mathrm{C}$-labelled intracellular myeloma protein and ${ }^{3} \mathrm{H}$-labelled extracellular myeloma, both harvested after separate $2 \mathrm{~h}$ incubations of plasma cells with radioactive amino acids. The chromatographic behaviour of intracellular and extracellular myeloma protein was found to be the same under all the chromatographic conditions tested (DEAEcellulose with elution at $\mathrm{pH} 6.5,7.0$ and 8.6 and CM-cellulose with elution at $\mathrm{pH} 6.5$; Fig. 2). A charge difference equivalent to the difference between two myeloma bands $a$ and $b$ would shift the elution pattern by 3-4 tubes on the DEAE. cellulose with the shallow gradient described. With the isoelectric-focusing technique, which has a
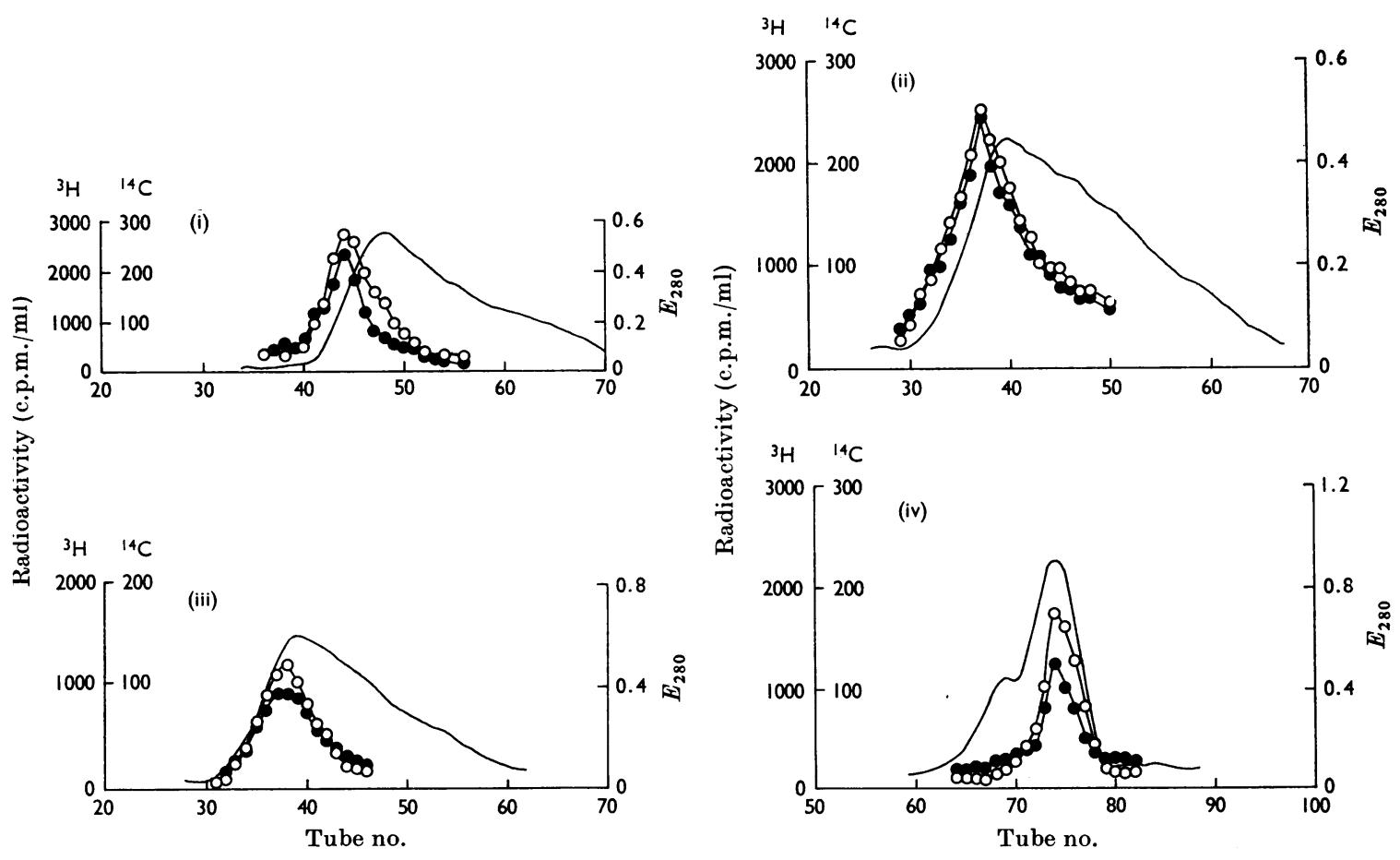

Fig. 2. Comparison of chromatographic properties of ${ }^{3} \mathrm{H}$-labelled extracellular and ${ }^{14} \mathrm{C}$-labelled intracellular 5563 myeloma protein. The radioactive myeloma proteins were prepared by incubating 5563 plasma cells for $1 \mathrm{~h}$ at $37^{\circ} \mathrm{C}$ with $\left[{ }^{3} \mathrm{H}\right]$ leucine and ${ }^{14} \mathrm{C}$-labelled amino acid mixture respectively. ——, $E_{280} ; O,{ }^{3} \mathrm{H}$-labelled protein precipitated with trichloroacetic acid; $\bullet,{ }^{14} \mathrm{C}$-labelled protein. Proteins were chromatographed on DEAE-cellulose [(i)-(iii)] or CM-cellulose (iv) in the following buffers: (i) potassium phosphate buffer, $\mathrm{pH} \mathrm{6.5}$; (ii) 10-50 mм-potassium phosphate buffer, pH 7.4; (iii) 10-50 mm-potassium phosphate buffer, pH 8.6; (iv) 5-50 mм-potassium phosphate buffer, $\mathrm{pH} 6.5$. 
much greater resolving power for charge differences, no charge difference could be found between intracellular and extracellular myeloma protein labelled during a $1 \mathrm{~h}$ pulse with ${ }^{14} \mathrm{C}$-labelled amino acid. The radioautograph of the isoelectric-focusing gel shows the presence of the same myeloma-protein components $o, o^{\prime}$ and $a$ both intracellularly and secreted by the cells during the $1 \mathrm{~h}$ pulse (Plate 1 ). Because of the rapidity with which components $o$ and $o^{\prime}$ undergo changes in charge properties some variation in the relative concentrations of components $o, o^{\prime}$ and $a$ within the cell and outside the cell is to be expected; it is clear from these results that some myeloma protein component $o$ is secreted by the cells apparently unchanged in isoelectric point. We can therefore find no evidence that the charge properties of 5563 myeloma protein change during the secretion process.

Search for N-terminal glutamine in freshly synthesized myeloma protein. The nature of the charge differences between myeloma proteins $o$ and $o^{\prime}$ and $a$ and the rapidity and totality of the conversion of components $o$ and $o^{\prime}$ into component $a$ raised the possibility that these initial changes towards a lower $\mathrm{p} I$ might be due to loss of $N$-terminal amino groups; in particular cyclization of $N$-terminal glutamine yielding pyrrolid-2-one-5-carboxylic acid was postulated.

Both light and heavy chains of 5563 myeloma protein were found to have blocked $N$-terminal groups. Reduced and alkylated myeloma proteins were fractionated into light and heavy chains by the method of Fleischman, Pain \& Porter (1962). Samples of light chain $(30 \mathrm{mg})$ and heavy chain (60 mg) were treated separately with 1 -fluoro-2,4dinitrobenzene and ether extracts of DNP-protein hydrolysate analysed by paper chromatography, with a full range of DNP-amino acids as markers (see the Materials and Methods section). Neither the heavy nor the light chain yielded a DNP-amino acid spot. Most heavy chains of immunoglobulins have been found to have blocked $N$-terminal end groups, which in some cases have been identified to be pyrrolid-2-one-5-carboxylic acid (Press, Piggott \& Porter, 1966). Some light chains, i.e. human $\lambda$-type chains and a low percentage of rabbit light chains have also been found to have pyrrolid-2-one-5carboxylic acid at the $N$-terminus (Putnam, 1967; Rüde \& Givol, 1968). One other mouse $\kappa$-type light chain has been found to have pyrrolid-2-one-5carboxylic acid at the $N$-terminus (Perham, Appella \& Potter, 1966). The 5563 myeloma protein has blocked $N$-terminal groups on heavy and light chains and it is reasonable to assume that both chain types have pyrrolid-2-one-5.carboxylic acid at their $N$-termini.

The theory that pyrrolid-2-one-5-carboxylic acid arises from modification of $N$-terminal glutamine after the completion of the peptide chain was tested as follows. Tumour 5563 cells were incubated at $37^{\circ} \mathrm{C}$ for $1 \mathrm{~h}$ with $\left[{ }^{14} \mathrm{C}\right]$ glutamine in the presence of an excess of non-radioactive L-glutamic acid. The ${ }^{14} \mathrm{C}$-labelled intra- and extra-cellular myeloma proteins were purified separately on DEAEcellulose; both preparations contain similar quantities of components $o, o^{\prime}$ and $a$ after 1 h of incubation (Plate 1). On hydrolysis with hydrochloric acid and amino acid analysis, $84 \%$ of the radioactivity was found to be present in the glutamic acid peak. To look for $N$-terminal $\left[{ }^{14} \mathrm{C}\right]$ glutamine the intracellular and extracellular myeloma proteins were treated with 1-fluoro-2,4-dinitrobenzene, carrier DNP-glutamine was added and the acid hydrolysates were extracted with ether. In three experiments less than $0.1 \%$ of the radioactivity in the protein was extracted by ether ; for example 14 c.p.m. was present in the ether extract compared with 24000 c.p.m. in the aqueous phase of the intracellular myeloma protein and 19000 c.p.m. in the extracellular myeloma protein. Carrier DNPglutamine was recovered as DNP-glutamic acid. The amount of radioactivity found corresponds to less than one-tenth of the value expected from the presence of only one $N$-terminal glutamine residue/ protein molecule.

We have therefore no evidence for $N$-terminal glutamine in newly assembled myeloma protein preparations that contained substantial amounts of components $o$ and $o^{\prime}$. This eliminates $N$-terminal cyclization as a cause of the changes from component $o$ to $o^{\prime}$ to $a$. The other implications are discussed below.

\section{DISCUSSION}

The differentiated neoplastic plasma cell forms a single molecular species of IgG, and therefore the cell must be expressing only a single structural gene for heavy chain and a single structural gene for light chain. This is not in conflict with the proposal that genetic information may be drawn from two different cistrons for each heavy chain and each light chain at the level of the stem cell because at the stage of the differentiated cell any two genes controlling a single polypeptide chain must have been integrated. This present evidence complements and reinforces the evidence from studies of single cells that showed that the product of the differentiated cell is limited and that pointed to allelic exclusion. This rigid allelic exclusion now demonstrated at the molecular level is perhaps more easily understood in terms of a pre-emptive specific induction of only one type of immunoglobulin molecule.

The reason why the homogeneity of the product of the plasma-cell tumour has been so difficult to 
demonstrate has become clear during these studies. After synthesis of a homogeneous Ig molecule the Ig is very susceptible to alterations in its charge properties, and both inside and outside the cell the product becomes heterogeneous. These alterations in charge properties occurring after synthesis fall into two categories.

(1) IgG component $o$, originally formed by the cell, is converted through an intermediate component $o^{\prime}$ into component $a$, the component of highest $\mathrm{p} I$ present in serum. This conversion begins very soon inside the cell and goes to completion after secretion from the cell. The approximate $\mathrm{p} K$ of the groups involved in these changes can be inferred from the behaviour of the newly formed radioactive G-myeloma protein when chromatographed at different $\mathrm{pH}$ values on DEAE-cellulose; the charge difference between component $o$ and component $a$ gradually decreases as the $\mathrm{pH}$ of chromatography is increased from 6.5 to 8.6. A pK of this order definitely excludes carboxyl groups and probably excludes $\epsilon$-amino groups of lysine, but leaves as possible candidates $\alpha$-amino groups and histidine residues. An unknown basic group with a slightly higher $\mathrm{p} K$ (about 8.5) has been shown to be involved in a single charge difference between two myoglobin components (Åkeson, 1962).

(2) Outside the cell, component $a$ is gradually converted into components of lower $\mathrm{p} I$. This appears to be an incomplete stepwise process that gives rise to the picture seen in serum of a series of five components $a-e$ present at progressively decreasing concentrations. In contrast with the first type of change, these charge differences are fully expressed between pH6.0 (i.e. near the isoelectric point) and pH 8.6 (Figs. 1 and 2). Suppression of these charge differences is only observed under acid conditions (e.g. electrophoresis at $\mathrm{pH} 3.2$, where myeloma protein and its constituent chains each run as a single band). This evidence is consistent with the idea that the ionizable groups involved in these charge differences are carboxyl groups. A progressive increase in the number of carboxyl groups could result from the loss of labile amide groups; single-charge differences due to the conversion of glutamine into glutamic acid between two myoglobin components have been described by Edmundson (1965) and loss of amide groups has been evoked to account for the heterogeneity of a number of other proteins (Edmundson \& Hirs, 1962; Edmundson, 1965). Moreover, Reisfeld (1967) found a decrease in amide content with increasing negative charge of subfractions of rabbit light chains.

Awdeh et al. (1967) reported that the slow partial conversion of component $a$ into more negatively charged components is pH-dependent and is accelerated by the presence of serum. The present studies have shown that the conversion of component $o$ into component $a$ is also enhanced by serum; this serum effect shows distinct $\mathrm{pH}$ dependence, being very slow at $\mathrm{pH} 6.5$ and quite rapid at $\mathrm{pH}$ 8.0. These serum and $\mathrm{pH}$ effects do suggest a possible role of enzymes; myeloma protein $a$ purified from serum also slowly undergoes conversion into $b$ and $c$ in the absence of added serum (Awdeh et al. 1967), but even in this case it is not possible to exclude enzyme action since purified Ig preparations have been shown by Robert \& Bockman (1967) to contain traces of proteolytic enzymes. Dr Robert kindly analysed our preparations of 5563 myeloma protein and found that these too contained a small amount of proteolytic activity.

Although a large measure of heterogeneity has already been induced in the newly synthesized myeloma protein by the time secretion of labelled protein commences, analysis by isoelectric focusing showed IgG components with the same $\mathrm{p} I$ present inside and outside the cells after $l \mathrm{lh}$ of incubation. Thus we have no evidence to support the idea that the secretion is related to a specific charge difference. In this respect the findings reported by Notani et al. (1966) should be noted; studying the radioactive products of tumour lines MOPC 21 and APC-5 by polyacrylamide electrophoresis at $\mathrm{pH} \mathrm{9.2,}$ these authors found that intracellular and secreted protein gave overlapping peaks displaced from each other by one tube. The method used by these authors did not reveal the known heterogeneity of APC-5 protein at alkaline $\mathrm{pH}$ and could not have detected differences between components of the types $o$ and $o^{\prime}$ reported here. In view of this lack of resolution the position of the radioactive peaks could well depend on the relative concentrations of different components changing with time. The presence of the same components inside and outside the cell cannot be excluded and therefore the results cannot be used to support a secretion-related charge difference.

Similar charge differences appear to separate adjacent components $o$ to $d$ (about $0.05 \mathrm{pH}$ unit between each component). Although we cannot be certain that the change between each component is equivalent to a single-charge difference, this appears to be the most likely explanation and is supported by a number of points. Perhaps the strongest argument stems from the finding that purified component $a$ gives rise to only a single light-chain and a single heavy-chain band on isoelectric focusing (Awdeh et al. 1969), and consequently the charge conversion of component $o$ into component $a$ must be a symmetrical one involving an even number of charge differences. This even number is assumed to be 2, i.e. one charge difference from component $o$ to component $o^{\prime}$ and one from component $o^{\prime}$ to component $a$, because no transitional forms have been 
detected. Direct evidence for a single-charge difference between adjacent light-chain bands has been obtained by alkylation of light chains with a negatively charged group, i.e. iodoacetic acid (Feinstein, 1966).

During this work the $\kappa$-type light chain of 5563 myeloma protein was found to have a blocked $N$ terminus. In human light chains blocked $N$-termini have been associated only with the $\lambda$-type chains (Putnam, 1967). This feature cannot be assigned purely to $\lambda$-chains, since in mouse Ig this is the second $\kappa$-chain with a blocked $N$-terminus (Perham et al. 1966).

The most likely origin of pyrrolid-2-one-5carboxylic acid would be via an enzymic cyclization of $N$-terminal glutamine. However, we have not been able to detect any incorporation of $\left[{ }^{14} \mathrm{C}\right]$ glutamine into $N$-terminal glutamine of myeloma protein synthesized during $1 \mathrm{~h}$. This result therefore excludes the possibility that $N$-terminal cyclization of glutamine is involved in the conversion of component $o$ into component $a$. Our findings, of course, do not exclude a very rapid formation of pyrrolid-2. one-5-carboxylic acid from $N$-terminal glutamine at the level of nascent peptide chains or immediately after assembly of the Ig molecules. Another alternative could be the conversion of glutamyl-tRNA into pyrrolid-2-one-5-carboxyl-tRNA, which has been reported in plant extracts (Bernfield \& Nestor, 1968). Attempts to demonstrate direct incorporation of radioactive pyrrolid-2-one-5-carboxylic acid into $\mathrm{Ig}$ in lymphoid tissue have been unsuccessful (Moav \& Harris, 1967).

The rapidity with which myeloma protein becomes heterogeneous after synthesis suggests that similar susceptibility to alterations in charge property should be considered to cause the limited heterogeneity of many other proteins.

Z.L.A. thanks the Lebanese National Institute for Scientific Research, Beirut, Lebanon, for their financial support.

\section{REFERENCES}

Åkeson, A. (1962). Dissertation: Medicinska Nobelinstitutet, Biokemiska Avdelningen, Stockholm.
Askonas, B. A. (1961). Biochem. J. 79, 33.

Askonas, B. A. \& Williamson, A. R. (1967). Proc. 3rd Nobel Symposium, p. 369. Ed. by Killander, J. Stockholm : Almqvist and Wiksell.

Awdeh, Z. L., Askonas, B. A. \& Williamson, A. R. (1967). Biochem. J. $102,548$.

Awdeh, Z. L., Williamson, A. R. \& Askonas, B. A. (1968). Nature, Lond., 219, 66.

Awdeh, Z. L., Williamson, A. R. \& Askonas, B. A. (1969). FEBS Lett. 5, 275.

Bernfield, M. R. \& Nestor, L. (1968). Biochem. biophys. Res. Commun. 33, 843.

Cebra, J. J., Colberg, J. E. \& Dray, S. (1966). J. exp. Med. $123,547$.

Chrambach, A., Reisfeld, R. A., Wyckoff, M. \& Zacarri, J. (1967). Analyt. Biochem. 20, 150.

Edmundson, A. B. (1965). Nature, Lond., 205, 883.

Edmundson, A. B. \& Hirs, C. H. W. (1962). J. molec. Biol. 5,663 .

Feinstein, A. (1966). Nature, Lond., 210, 135.

Fleischman, J. B., Pain, R. \& Porter, R. R. (1962). Archs Biochem. Biophys. Suppl. 1, 174.

Hanks, J. H. (1948). J. cell. comp. Physiol. 31, 235.

Lennox, E. S. \& Cohn, M. (1967). A. Rev. Biochem. 36, 365 .

Levy, A. L. (1954). Nature, Lond., 174, 126.

Moav, B. \& Harris, T. N. (1967). Biochem. biophys. Res. Commun. 29, 773.

Notani, G. W., Munro, A. J. \& Knopf, P. M. (1966). Biochem. biophys. Res. Commun. 25, 395.

Perham, R., Appella, E. \& Potter, M. (1966). Science, N.Y., 154, 391 .

Pernis, B., Chiappino, G., Kelus, A. \& Gell, P. G. H. (1965). J. exp. Med. 122, 853.

Peterson, E. A. \& Sober, H. A. (1956). J. Am. chem. Soc. 78, 751 .

Phillips, D. M. P. (1958). Biochem. J. 46, 304.

Press, E. M., Piggott, P. J. \& Porter, R. R. (1966). Biochem. J. 99, 356.

Putnam, F. W. (1967). Proc. 3rd Nobel Symposium, p. 45. Ed. by Killander, J. Stockholm : Almqvist and Wiksell.

Reisfeld, R. A. (1967). Cold Spring Harb. Symp. quant. Biol. 32, 291.

Robert, B. \& Bockman, R. S. (1967). Biochem. J. 102, 554.

Rüde, E. \& Givol, D. (1968). Biochem. J. 107, 449.

Williamson, A. R. \& Askonas, B. A. (1967). J. molec. Biol. 23, 201.

World Health Organisation (1964). Bull. Wld Hlth Org. 30, 447. 